\title{
COMPENSATORY MEASURES IN EUROPEAN NATURE CONSERVATION LAW: A STATE-OF-THE- ART AFTER THE BRIELS CASE AND THE ACHELOOS RIVER CASE
}

\author{
Geert Van Hoorick ${ }^{*}$
}

\begin{abstract}
The Birds and Habitats Directives are the cornerstones of EU nature conservation law, aiming at the conservation of the Natura 2000 network, a network of protected sites under these directives, and the protection of species. The protection regime for these sites and species is not absolute: member states may, under certain conditions, allow plan or projects that can have an adverse impact on nature. In this case, compensatory measures can play an important role in safeguarding the Natura 2000 network and ensuring the survival of the protected species. This contribution analyses whether taking compensatory measures is always obligatory, and discusses the aim and the characteristics (i.a. the naturalness) of compensatory measures, in relation to other kinds of measures such as mitigation measures, usual nature conservation measures, and former nature development measures, and to the assessment of the adverse impact caused by the plan or project and of the alternative solutions. The questions will be discussed in light of the text of the legislation, the guidance and practice by the European Commission, (legal) doctrine and case law, mainly of the Court of Justice (the Briels case and the Acheloos River case).
\end{abstract}

INTRODUCTION..................................................................... 175

I. TEXT OF ARTIClE 6(4) OF THE HABITATS DiRECTIVE ...........................176

II. COMPENSATORY VS. Mitigation MEASURES—THE BRIELS CASE ........ 177

III. COMPENSATORY MEASURES VS. USUAL NATURE CONSERVATION

MEASURES ....................................................................... 180

IV. AIM OF COMPENSATORY MEASURES: IN-KIND COMPENSATION............ 181

V. SIMULTANEOUSNESS AND FEASIBILITY OF COMPENSATORY MEASURES 182 VI. QUALITATIVE AND QUANTITATIVE MEASURES: COMPENSATION RATIOS

VII. COMPENSATION BEFOREHAND: COMPENSATION VS. NATURE

DEVELOPMENT MEASURES AND HABITAT BANKING ............................... 186

VIII. IMPOSSIBLE COMPENSATION .................................................... 187

IX. BiologicAl InTEGRity VS. MAN-MADE NATURE-ThE ACHELOOS

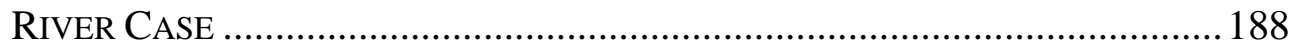

\footnotetext{
* Department for European, Public and International Law, Centre for Environmental and Energy Law, Law Faculty, Ghent University, Ghent (Belgium). Research fields: Nature, Wildlife and Heritage Conservation Law, Town and Country Planning Law, Animal Law.
} 
X. The Costs of the Compensatory Measures: Opinion of the

COMMISSION

XI. DEROGATIONS FROM SPECIES PROTECTION AND COMPENSATORY

MEASURES

CONCLUSION. 193

\section{INTRODUCTION}

The Birds and Habitats Directives ${ }^{1}$ are the cornerstones of EU nature conservation law, aiming at the conservation of the Natura 2000 network, a network of protected sites under these directives, and the protection of species. In this contribution, we will discuss the obligations of the Member States to compensate for biodiversity loss in the framework of Articles 6(4) and 16(1) of the Habitats Directive. The first provision requires the Member States to take compensatory measures to ensure the coherence of Natura 2000 in cases where plans or projects causing negative impacts have been allowed because of overriding public interests, the latter provision requires them to take measures to maintain a favourable conservation status for protected species in cases where derogations from the species protection measures of the Habitats Directive have been granted. We will focus on the relationship among compensation, mitigation, and conservation (usual nature conservation measures, nature development measures), and the assessment of alternative solutions. We will discuss the questions in light of the text of the legislation, the guidance provided by the European Commission services, the practice of the issued opinions of the Commission, (legal) doctrine and case law, mainly of the Court of Justice. For a long time European case law regarding the characteristics of compensatory measures had been non-existent, but in 2012 the Acheloos River case in Greece was judged by the Court of Justice ${ }^{2}$ on a reference for a preliminary ruling, and in 2014 the same happened with the Briels case in the Netherlands ${ }^{3}$. Therefore, we will focus on these two cases ${ }^{4}$.

\footnotetext{
${ }^{1}$ Directive 2009/147/EC of 30 November 2009 on the conservation of wild birds, OJ L 207 (Jan. 26, 2010); Council Directive 92/43/EEC of 21 may 1992 on the conservation of natural habitats and of wild fauna and flora, OJ L 5963 (Mar. 8, 1996); see The HABITATS DiRECTIVE IN ITS EU Environmental LaW ConteXt. European NATURE's Best Hope? 520 (Ch.-H. Born, A. Cliquet, H. Schoukens, D. Misonne and G. Van Hoorick eds., Oxford, Routledge 2014).

${ }^{2}$ Case 43/10, Nomarchiaki Aftodioikisi Aitoloakarnanias v Ipourgos Perivallontos, ECLI: EU: C: 2012: 560 (2012).

${ }^{3}$ Case 521/12, T.C. Briels and Others v Minister van Infrastructuur en Milieu, ECLI: EU: C: 2014: 330 (2014).

${ }^{4}$ See for an outline before the Briels case was judged G. Van Hoorick, Compensatory Measures in European Nature Conservation Law, 10(2) UTRECHT LAW REVIEW 161 -171 (2014).
} 


\section{TeXt of ARticle 6(4) of the Habitats Directive}

The obligation relating to compensatory measures in Article 6(4) of the Habitats Directive is formulated as follows:

If, in spite of a negative assessment of the implications for the site and in the absence of alternative solutions, a plan or project must nevertheless be carried out for imperative reasons of overriding public interest, including those of a social or economic nature, the Member State shall take all compensatory measures necessary to ensure that the overall coherence of Natura 2000 is protected. It shall inform the Commission of the compensatory measures adopted.

Where the site concerned hosts a priority natural habitat type and/or a priority species, the only considerations which may be raised are those relating to human health or public safety, to beneficial consequences of primary importance for the environment or, further to an opinion from the Commission, to other imperative reasons of overriding public interest.

The provision aims at taking compensatory measures in case of damage to Natura 2000 sites when negative plans or projects have been allowed because of overriding public interests.

For the interpretation of the obligation relating to compensatory measures, besides the two already mentioned judgments of the Court of Justice, there is a guidance document of the Commission on Article 6(4) that can be useful. However, it reflects the views of the Commission services only and is not of a binding nature. Nevertheless, it can be very helpful and we can be certain that the Court of Justice tends to look at such guidance documents. ${ }^{6}$ Up until now, the Commission has issued 20 opinions under Article 6(4)(2), ${ }^{7}$ and although these opinions are difficult to evaluate for an outside observer, they at least provide an insight into how the compensation obligation is dealt with in practice. ${ }^{8}$ There exists also some legal doctrine ${ }^{9}$ about the topic, and in some Member States also national

\footnotetext{
${ }^{5}$ European Commission, Guidance document on Article 6(4) of the "Habitats Directive” 92/43/EEC (2007). http://ec.europa.eu/environment/nature/natura2000/management/docs/art6/guidance_art6_4_en.pdf. (last visited November 19, 2014).

${ }^{6}$ E.g. Case 182/10, Solvay and Others, ECLI: EU: C: 2012: 82, Para. 28 (2012).

${ }^{7}$ http://ec.europa.eu/environment/nature/natura2000/management/opinion_en.htm (last visited November 19, 2014).

${ }^{8}$ See L. Krämer, The European Commission's Opinions under article 6(4) of the Habitats Directive, 21(1) J. EnV. L. 59-85 (2009); D. McGillivray, Biodiversity Loss: The EU Commission's Approach to Compensation under Article 6 of the Habitats Directive, 24 J. ENV. L. 417-450 (2012).

${ }^{9}$ E.g. F. Haumont, L'application des Measures Compensatoires prévues par Natura 2000, 10 ERA FoRUM 611-624 (2009); D. McGillivray, Biodiversity Loss: The EU Commission's Approach to Compensation under Article 6 of the Habitats Directive, 24 J. ENV. L. 417-450 (2012).
} 
case law. $^{10}$

\section{Compensatory vs. Mitigation Measures-The Briels CASE}

The term compensatory measures are not defined in the Habitats Directive. In the Guidance document, ${ }^{11}$ a distinction is made between mitigation measures (those measures which aim to minimize, or even cancel, the negative impacts on a site that are likely to arise as a result of the implementation of a plan or project) and compensatory measures (those measures which are independent of the project, including any associated mitigation measures, and are intended to offset the negative effects of the plan or project so that the overall ecological coherence of the Natura 2000 Network is maintained). Let us give an example: If the plan or project is the construction of a motorway, an eco-duct to connect the populations of the negatively affected species amounts to "mitigation", the creation of a new habitat for the affected species is "compensation". The meaning of mitigation here is close to the definition used in the European doctrine: ${ }^{12}$ minimization, such as limiting or reducing the degree, extent, magnitude or duration of adverse impacts, by scaling down, relocating or redesigning elements of a project. In the Commission's opinions, for example, the following measures were regarded as mitigation measures: an extension of a bridge over a river to reduce the impact on alluvial forests, ${ }^{13}$ noise barriers, ${ }^{14}$ a 300-meter viaduct, ${ }^{15}$ anti-collision barriers of four meters for bats, ${ }^{16}$ the removal of temporary construction roads after completion, ${ }^{17}$ collecting and relocating protected species (e.g. bulbs and reptiles), ${ }^{18}$ prohibiting construction activities at night ${ }^{19}$ or dredging activities during spawning times, ${ }^{20}$ postponing the time frame for felling trees during the breeding season, $^{21}$ and speed limits for ships to reduce the intensity of their

\footnotetext{
${ }^{10}$ See e.g. H. Schoukens \& A. Cliquet, Mitigation and Compensation under EU Nature Conservation Law in the Flemish Region: Beyond the Deadlock for Development Projects?, 10(2) UTRECHT LAW REVIEW 194-215 (2014).

${ }^{11}$ Guidance Document, supra note 5, at 10.

${ }^{12}$ K. Rundcrantz \& E. Skärbäck, Environmental Compensation in Planning: A Review of Five Different Countries with Major Emphasis on the German System, 13(4) EUR. ENV. 206 (2003).

${ }^{13}$ Opinion in Motorway A 49.

${ }^{14}$ Opinion in Peene.

${ }^{15}$ Opinion in TGV East.

${ }^{16}$ Opinion in Motorway A 20.

${ }^{17}$ Opinion in Motorway A 49.

${ }^{18}$ Opinion in Györ.

${ }^{19}$ Opinion in Motorway A 20.

${ }^{20}$ Opinion in River Elbe.

${ }^{21}$ Opinion in River Main.
} 
waves. ${ }^{22}$ The measures which the Commission regarded as compensatory were in all cases the creation or restoration of the affected habitat types or species' habitats. By the way, contrary to the European doctrine, in the USA "mitigation" includes "compensation by replacement or substitution"23.

The clear distinction in the EU, which distinguishes mitigation from compensatory measures, is not only of academic value but necessary so as not to jeopardize a sound assessment of the adverse effects of the plan or project and of the alternative solutions, and not to circumvent the application of Article 6(4) in cases of a negative impact. Otherwise, combining an environmentally bad plan or project with strong compensatory measures could supersede a better alternative plan or project combined with weak compensatory measures, or could even be allowed without need to apply the derogation regime of Article 6(4). This cannot be the purpose of the Habitats Directive, because, as stated in the Guidance document, ${ }^{24}$ it is widely acknowledged that it is highly unlikely that by taking compensatory measures the conservation status of the related habitats and species can be reinstated to the level they had before the damage by a plan or project. Mitigation measures, however, are an integral part of the specifications of a plan or project. $^{25}$

Thus, compensatory measures should be considered only after having ascertained a negative impact on the integrity of a Natura 2000 site. $^{26}$ Specifically, the logic and rationale of the assessment process require that if a negative impact is foreseen, then an evaluation of alternatives should be carried out as well as an appreciation of the interest of the plan or project in relation to the natural value of the site. Once it is decided that the plan or project should proceed, then it is appropriate to move on to a consideration of compensatory measures. ${ }^{27}$

\footnotetext{
${ }^{22}$ Opinion in River Elbe.

${ }^{23}$ E.g. J.B. Zedler, Ecological Issues in Wetland Mitigation: An Introduction to the Forum, 6(1) ECOLOGICAL APPLICATIONS 33-37 (1996).

${ }^{24}$ Guidance Document, supra note 5, at 17.

${ }^{25}$ Guidance Document, supra note 5, at 10.

${ }^{26}$ Case 182/10, Solvay and Others, ECLI: EU: C: 2012: 82, Paras. 73 and 74 (2012); Case C-258/11, Sweetman and Others, ECLI: EU: C: 2013: 220, Para. 35 (2013).

${ }^{27}$ Guidance Document, supra note 5, at 11; Opinion given by the Advocate General in Case 239/04, Commission v Portuguese Republic, Para. 35; In conformity there with in Belgium the Raad van State (this is the highest administrative court in Belgium) (RvS 29 November 2011, no. 216. 548, vzwNatuurpunt Limburg and Others; RvS 29 March 2013, no. 223.083, vzwNatuurpunt Limburg and Others, www.raadvst-consetat.be) ruled that nature development measures (the creation of habitats by the expropriation of agricultural land) accompanying a motorway project could not be seen as mitigation measures to take away the negative effects of the plan or project, and therefore could not be taken into account in the appropriate assessment. These measures were clearly compensatory measures.
} 
In the judgment in the Briels case, the Court of Justice supports this vision. This case was brought to the Court by a request for a preliminary ruling from the Raad van State (Council of State) of the Netherlands. ${ }^{28}$ The Raad van State wanted to know if the phrase "not adversely affect the integrity of the site" in Article 6(3) has to be interpreted as follows: When the project adversely affects the area of a protected natural habitat type within the site, the integrity of the site is not adversely affected if in the framework of the project an area of that natural habitat type of equal or similar size is created within that site.

The case is about the widening of the A2 motorway towards Eindhoven, which has a negative impact on the Natura 2000 site VlijmensVen, Moerputten \& Bossche Broek, designated for, in particular, the natural habitat type molinia meadows, which is a non-priority habitat type. The assessment concluded that the A2 motorway project would cause the drying out and acidification of molinia meadows (acidification due to nitrogen deposits). In accordance with the viewpoint in the assessment, the Dutch government lessened the environmental impact by hydrological measures in another molinia meadow in the planning area, which would then develop into a high-quality habitat. The question is whether these measures can be seen as mitigation, preventing the application of Article 6(4), or as compensation in the sense of Article 6(4). By the way, the project has meanwhile been completed.

Briels and others brought an action against the two ministerial orders before the referring court. In their viewpoint, the Minister could not lawfully adopt the orders for the A2 motorway project, given the negative implications of the widening of the A2 motorway for the Natura 2000 site in question. They argue that the development of new molinia meadows on the site, as provided for by the ministerial orders at issue in the main proceedings, could not be taken into account in determining whether the site's integrity was affected. They submit that such a measure cannot be categorised as mitigation, a concept which is, moreover, non-existent in the Habitats Directive.

The Court rejects the view of the Dutch government and regards the measures as compensatory measures. The Court held that the application of the precautionary principle in the context of the implementation of Article 6(3) requires the competent national authority to assess the implications of the project for the concerned Natura 2000 site in view of the site's conservation objectives and taking into account the protective measures

\footnotetext{
${ }^{28}$ ABRvS 7 November 2012, 201110075/1/R4 en 20120185/1/R4.
} 
forming part of that project and aimed at avoiding or reducing any direct adverse effects for the site, in order to ensure that it does not adversely affect the integrity of the site ${ }^{29}$. The Court clearly refers hereby to mitigation measures, however without using the word. The Court adds that protective measures provided for in a project which are aimed at compensating for the negative effects of the project on a Natura 2000 site cannot be taken into account in the assessment of the implications of the project provided in Article $6(3)^{30}$. As main reason for this viewpoint, the Court mentions that the positive effects of a future creation of a new habitat are difficult to forecast and will be visible only several years into the future ${ }^{31}$. As second reason for this viewpoint, the Court points out that the effectiveness of the mitigation measures is intended to avoid a situation where competent national authorities allow so-called "mitigating" measures, which are in reality compensatory measures, in order to circumvent the specific procedures provided in Article 6(3) and authorize projects which adversely affect the integrity of the site concerned ${ }^{32}$. Authorization for the project therefore needs to be given in accordance with the procedure for compensation measures, provided for in Article 6(4).

\section{COMPENSATORY MEASURES VS. USUAL NATURE CONSERVATION MEASURES}

It is obvious, as it is stated in the Guidance document, ${ }^{33}$ that compensatory measures should go beyond the normal or standard measures required for the protection and management of Natura 2000 sites. But because space is limited and "naturalizing" agricultural or other intensively used land often meets strong opposition from farmers or other people, governments sometimes prefer to take qualitative compensation measures in existing Natura 2000 sites, thus enhancing their ecological value.

It is not always easy to determine in a real case what the normal or standard measures required for the protection and management of Natura 2000 sites are. A clear criterion could be the conservation status of the related habitats and species in the Natura 2000 site where the compensatory measures are taken: In principle, as long as the conservation status of the related habitats and species in this site is not favourable, "compensatory measures" in this site cannot be regarded as going beyond the normal or

\footnotetext{
${ }^{29}$ Case 521/12, supra note 3, Para. 28.

${ }^{30}$ Case 521/12, supra note 3, Para. 29.

${ }^{31}$ Case 521/12, supra note 3, Para. 32.

${ }^{32}$ Case 521/12, supra note 3, Para. 33.

${ }^{33}$ Guidance Document, supra note 5, at 10.
} 
standard measures for the protection and management of Natura 2000 sites, and the Member State should have the burden of proving the opposite. ${ }^{34}$

\section{Aim OF COMPENSATORY MEASURES: IN-KIND COMPENSATION}

According to Article 6(4) of the Habitats Directive, the compensatory measures have to ensure that the overall coherence of Natura 2000 is protected. This provision is linked with Article 3(1), requiring the member states that the Natura 2000 network enables the concerned habitats and species to be maintained or restored at a favourable conservation status in their natural range. Hence, according to the guidance document ${ }^{35}$, two different criteria are considered, on the one hand the targeted species and habitats in terms of quantity and quality, and on the other hand the role of the site in ensuring the adequate geographical distribution in relation to the range. Compensation should refer to the site's conservation objectives, a notion mentioned in Article 6(3), and to the habitats and species negatively affected in comparable proportions in terms of number and status. At the same time, the role played by the site concerned in relation to the biogeographical distribution has to be replaced adequately. According to the guidance document ${ }^{36}$, this is by analogy similar to the specially protected areas under the Birds Directive. In all Commissions' opinions, the Commission stresses that the compensatory measures have to ensure the overall coherence of Natura 2000, and except for the very first opinions the Commission does check this. In one case, the Commission considered itself unable to fully assess whether the compensatory measures and their timing would ensure overall coherence of Natura $2000^{37}$.

The term compensation here is used in the sense of what's called in

\footnotetext{
${ }^{34}$ In Belgium there was a case before the Raad van State (RvS 30 July 2002, no. 109.563, Apers and others, www.raadvst-consetat.be) in which it was determined that nature development measures at a proposed site of Community interest under the Habitats Directive could not be seen as compensatory measures in the sense of Article 6(4) of the Habitats Directive for the destruction of a special protection area under the Birds Directive because of overriding public interests, given that the Habitats Directive itself obliges the Member States to ensure a sound management of these sites. This judgment gave rise to some critical remarks in legal doctrine (H. SCHOUKENS ET AL., HANDBOEK NATUURBEHOUDSRECHT 226 (Oxford-Antwerp, Intersentia 2011) because, as mentioned, the Habitats Directive and the Guidance document do not exclude such compensatory measures as such. Assuming that it was not evident that in the Belgian case the compensatory measures did go beyond the normal or standard measures required for the protection and management of Natura 2000 sites, the judgement of the Raad van State can be seen as being correct.

${ }^{35}$ Guidance Document, supra note 5, at 11.

${ }^{36}$ See Guidance Document, supra note 5, at 12.

${ }^{37}$ Because Germany hadn't at that time yet proposed a sufficient number of sites according to Article 4 of the Habitats Directive (Opinion in Mühlenberger Loch).
} 
doctrine $^{38}$ "restoration compensation": environmental compensation for lost environmental values in the right functional context (on-site, in-kind compensation), with the nuance that on-site has to be understood somewhat broad in the sense of "within the biogeographical region" and not necessary on the same Natura 2000 site. Certainly the compensation has to be in-kind (e.g. dry heathland by dry heathland) and within the functional context of the coherence of the Natura 2000 network. In all Commissions' opinions, the Commission checks the link with the global coherence of Natura 2000 and the correspondence between the affected habitat and the created or restored compensatory habitat.

\section{SimultanEOUSNESS AND FEASIBILITY OF COMPENSATORY MEASURES}

The guidance document derives some characteristics from the aim of compensatory measures. Basically the result of implementing compensation should be operational once the damage is effective on the site concerned, but it is acknowledged that there can be certain circumstances where this can't be completely fulfilled (the guidance document gives as example a forest habitat ${ }^{39}$ : The trees need decades to grow before restoring the functionality of the forest habitat). However, compensatory measures require that a sound legal and financial basis for long-term implementation and for their protection, monitoring and maintenance be secured in advance of impacts upon habitats or species occur ${ }^{40}$. Compensatory measures must be feasible and operational in reinstating the ecological conditions needed to ensure the overall coherence of the Natura 2000 network (i.e. the ecological structure and functions impaired and the habitats and species involved). The estimated timescale and any maintenance action required to enhance performance should be known and foreseen right from the start in view of the implementation of the measures. This must be based on the best scientific knowledge available, complemented with specific investigations for the precise location where the compensatory measures will be implemented ${ }^{41}$. Its first opinion ${ }^{42}$ on the Commission has stressed that the compensatory measures have to be taken simultaneously with the damaging activities, and in several opinions, the Commission accepts the compensatory measures under the condition that they are executed in a

\footnotetext{
${ }^{38}$ K.Rundcrantz \& E.Skärbäck, Environmental Compensation in Planning: A Review of Five Different Countries with Major Emphasis on the German System, 13(4) EUR. ENV. 206 (2003).

${ }^{39}$ Guidance Document, supra note 5, at 14.

${ }^{40}$ Guidance Document, supra note 5, at 19.

${ }^{41}$ Guidance Document, supra note 5, at 16.

${ }^{42}$ Opinion in Peene.
} 
timely manner ${ }^{43}$. In more recent opinions, the Commission even considers it necessary that the compensatory measures are completed before beginning the damaging activities ${ }^{44}$. In one case, ${ }^{45}$ two existing Natura 2000 sites will be linked by means of compensatory measures.

Measures without reasonable guarantee of success should not be considered. The most effective option, allowing for the greatest chances of success must be chosen when it comes to deciding between different possibilities of compensation. The program of compensatory measures needs to include detailed monitoring during implementation to ensure effectiveness in the long term ${ }^{46}$. Let alone a few early opinions, the Commission always requires that a monitoring system must be put in place ${ }^{47}$, and that the results of the monitoring must be taken into account and may lead to additional compensatory measures ${ }^{48}$. In some opinions, the Commission accepts compensatory measures only under the condition of providing maintenance measures for the compensatory habitats ${ }^{49}$ or their long-term effectiveness ${ }^{50}$. That the Commission doesn't exclude a priori management contracts with farmers for the conservation of compensatory habitats ${ }^{51}$, doesn't affect the requirement for monitoring and achieving a long-term conservation; it's up to the national governments to change to compulsory instruments if necessary.

The costs of compensatory measures should not be taken into account while evaluating this effectiveness: They must be seen as part of the total costs of the plan or project. If the costs are considered too high, it should withhold the promoter to initiate the plan or project and stimulate him to search for alternative plans or projects that are less harmful for Natura 2000. The costs of compensatory measures for plan or projects with a large impact can be huge, e.g. in the case of the La Breña water reservoir in Spain, ${ }^{52}$ the main compensatory measure was to expropriate 15 estates with a total area of more than 2.100 ha to create habitat and food for the Iberian lynx.

\footnotetext{
${ }^{43}$ E.g. Opinion in La Breña.

${ }^{44}$ E.g. Opinions in Granadilla and Motorway A 20.

${ }^{45}$ Opinion in Motorway A 49.

${ }^{46}$ Guidance Document, supra note 5, at 17.

${ }^{47}$ E.g. Opinions in Prosper Haniel, TGV East and La Breña.

${ }^{48}$ The same applies to mitigation measures; E.g. Opinion in TGV East.

${ }^{49}$ E.g. Opinion in Györ.

${ }^{50}$ Opinion in TGV East.

${ }^{51}$ Opinion in TGV East.

${ }^{52}$ Opinion in La Breña. In this case the Spanish government proposed compensatory measures for more than $€ 28$ million.
} 


\section{Qualitative And Quantitative MeAsures: Compensation Ratios}

It seems that there are two kinds of compensation measures related to Natura 2000 sites: qualitative measures enhancing the ecological quality of an existing site, and quantitative measures protecting a non-designated site by designating it as part of the Natura 2000 network (of course mostly combined with qualitative measures in that site, because only that legal status will not be sufficient to ensure the coherence of the Natura 2000 network). One of the principles in European policy is "no net-loss" of biodiversity ${ }^{53}$. This can only be achieved by an obligation to take quantitative compensatory measures in cases where (a part of) a Natura 2000 site is destroyed as a result of allowing development on that land (a motorway, an extension of a seaport, a housing project, etc.). Otherwise, the surface of the Natura 2000 network and therefore the coherence of the Natura 2000 network would shrink.

The guidance document supports that vision in the passage about compensation ratios. Even if the guidance document accepts as compensatory measures not only the recreation of a habitat, or the proposal of a new site, but also the biological improvement of a substandard habitat within an existing designated site ${ }^{54}$, it states that the extent required for the compensatory measures to be effective has a direct relationship to the quantitative and qualitative aspects inherent to the elements of integrity (i.e. including structure and functionality and their role in the overall coherence of the Natura 2000 network) likely to be impaired and to the estimated effectiveness of the measures ${ }^{55}$. The compensation ratios are best set on a case-by-case basis and must be initially determined in light of the information managed during Article 6(3) assessment and ensuring the minimum requirements to meet ecological functionality ${ }^{56}$. Implicitly, the guidance document stands for quantitative measures in case of a decline in surface of a Natura 2000 site. There is wide acknowledgement that ratios should be generally well above $1: 1$. Thus, compensation ratios of $1: 1$ or below should only be considered when it is demonstrated that with such an extent, the measures will be $100 \%$ effective in reinstating structure and functionality within a short period of time (e.g. without compromising the

\footnotetext{
${ }^{53}$ European Commission, Our Life Insurance, Our Natural Capital: An EU Biodiversity Strategy to 2020, 244 final, 12 (COM 2011); D. McGillivray, Compensating Biodiversity Loss: The EU Commission's Approach to Compensation under Article 6 of the Habitats Directive, 24(3) J. ENV. L. 421 (2012).

${ }^{54}$ Guidance Document, supra note 5, at 14.

${ }^{55}$ Guidance Document, supra note 5, at 17.

${ }^{56}$ Guidance Document, supra note 5, at 17.
} 
preservation of the habitats or the populations of key species likely to be affected by the plan or project) ${ }^{57}$. If compensation can't be completely operational at the time when the damage is effective on the site concerned, overcompensation ${ }^{58}$ would be required for the interim losses ${ }^{59}$. Compensation in a non-designated location is acceptable, but must be accompanied by a designation as part of the Natura 2000 network $^{60}$, otherwise a long-term coherence of Natura 2000 would not be ensured.

It appears that in many cases submitted for a Commission's opinion, member states apply compensation ratios of more than $1: 1$. We can see ratios of $1: 2^{61}$ and $1: 3^{62}$, over $1: 4$ and $1: 7^{63}$ till $1: 10^{64}$ and even $1: 12^{65}$. It depends on the recreation time of the habitat types which can go beyond several decades ${ }^{66}$. In some cases, ${ }^{67}$ member states make a very useful distinction between the compensation of direct habitat loss (by land occupation) and the compensation of indirect habitat loss (by gradually negative impact). It is not always clear from the Commission's opinions ${ }^{68}$ whether the compensatory habitats are in or outside Natura 2000 and if outside, whether the Commission really requires, they will be designated as part of Natura 2000. In some cases, ${ }^{69}$ the member state proposes the creation of compensatory habitat notwithstanding the adversely affected habitats will in time be brought back into the Natura 2000 network.

\footnotetext{
${ }^{57}$ Guidance Document, supra note 5, at 18.

${ }^{58}$ The term "overcompensation" is used in the Guidance document. However, the correct name is maybe rather "compensatory remediation" in the sense of Annex II of Directive 2004/35/CE of the European Parliament and of the Council of 21 April 2004 on environmental liability with regard to the prevention and remedying of environmental damage, OJ L 143, 30.04.2004, 56: “1. (c)

'Compensatory' remediation is any action taken to compensate for interim losses of natural resources and/or services that occur from the date of damage occurring until primary remediation has achieved its full effect; (d) 'interim losses' means losses which result from the fact that the damaged natural resources and/or services are not able to perform their ecological functions or provide services to other natural resources or to the public until the primary or complementary measures have taken effect. It does not consist of financial compensation to members of the public."

${ }^{59}$ Guidance Document, supra note 5, at 19.

${ }^{60}$ Guidance Document, supra note 5, at 14.

${ }^{61}$ Opinions in Lübeck Airport and B 252/B 62.

${ }^{62}$ Opinions in Prosper Haniel, La Breña, River Elbe, Motorway A 20 and B 252/B 62.

${ }^{63}$ Opinion in River Main.

${ }^{64}$ Opinion in Karlsruhe Airport.

${ }^{65}$ Opinion in Motorway A 20.

${ }^{66}$ Opinion in River Main.

${ }^{67}$ Opinion in $B$ 252/B 62.

${ }^{68}$ E.g. Opinions in Prosper Haniel and La Breña.

${ }^{69}$ Opinion in Karlsruhe Airport.
} 


\section{COMPENSATION BEFOREHAND: COMPENSATION VS. NATURE DEVElopment MEASURES AND HaBitat BANKING}

In practice, there is a need for a more comprehensive and proactive approach towards compensation, in which the assessment of several (succeeding or territorially close) negative plans and projects in a certain region (e.g. a seaport) and also the compensatory measures are bundled and handled early on during the planning phase. But questions arise as to whether the Birds and Habitats Directives can deal with this need for flexibility and whether this approach could possibly endanger the Natura 2000 network.

In the guidance document, it is mentioned several times ${ }^{70}$ that a caseby-case approach is appropriate, but by using the word plan, Article 6(3) of the Habitats Directive provides some room for a comprehensive approach: several (succeeding or territorially close) projects can be included in one plan (e.g. for the development of a seaport). The guidance document states that best efforts should be made to assure compensation is in place before hand ${ }^{71}$ (i.e. before the damage to Natura 2000 is caused), thus not prohibiting a proactive approach, and in recent opinions ${ }^{72}$ the Commission has considered it necessary that the compensatory measures are completed before the beginning of the damaging activities. But there seems to be limits as to how long beforehand the compensation should be in place. Given the link with the damage that will be caused and the appropriate assessment, and the strict requirement that compensation should ensure the coherence of the Natura 2000 network, it seems that there is only little room for formerly taken nature development measures in the area to be regarded as compensatory measures under Article 6(4) of the Habitats Directive. The same applies to habitat banking, ${ }^{73}$ as the Guidance document ${ }^{74}$ considers it as rarely useful in the framework of compensation. This does not have to discourage Member States from taking nature development measures or

\footnotetext{
${ }^{70}$ E.g. Guidance Document, supra note 5, at 17 and 19.

${ }^{71}$ Guidance Document, supra note 5, at 13.

${ }^{72}$ E.g. opinion in Granadilla and Motorway A 20.

${ }^{73}$ G. Van Hoorick, Innovative Legal Instruments for Ecological Restoration, in LiBER AMICORUM HuBERT BoCKen. DARE LA LUCE 483-488 (I. Boone et al. eds., 2009). Two studies commissioned by the Commission have been made on this topic: REMEDE, Compensation in the Form of Habitat Banking. Short Case Study Report (2008). http://www.envliability.eu/docs/D12CaseStudies/D12CaseStudies.html. (last visited November 19, 2014); EFTEC, IEEP et. al, The Use of Market-based Instruments for Biodiversity Protection - The Case of Habitat Banking - Summary Report (2010). http://www.ieep.eu/workareas/biodiversity/2010/02/the-use-of-market-based-instruments-for-biodiversity-protection-the-caseof-habitat-banking. (last visited November 19, 2014).

${ }^{74}$ Guidance Document, supra note 5, at 16.
} 
setting up habitat banking for Natura 2000 sites beforehand, because these measures can enhance the conservation status of the related habitat and species, and by doing so, making them less vulnerable to damage, i.e. requiring a higher damage level to qualify the effect of the plan or project as significant within the meaning of Article 6(3) of the Habitats Directive. In light of the above discussed requirements of compensatory measures, the nature development measures or the newly developed habitats in the habitat banking system have to be operational a considerable time before the plan or project affecting Natura 2000 is put in place; only under these circumstances can the result of these measures legally play a role in the appropriate assessment.

\section{IMPOSSIBLE COMPENSATION}

A problem that the guidance document ${ }^{75}$ only addresses shortly, is that some habitat types can't be compensated because they are rare or need a long period for providing the same ecological functionality (e.g. raised bogs need more than thousands of years to develop): "under these circumstances, the zero option should be seriously considered". Also the guidance document ${ }^{76}$ states that the likely success of the compensation scheme should influence the final approval of the plan or project in compliance with the preventive principle.

One should acknowledge that the zero option should always be seriously considered and that even in many common cases, compensation will not yet be effective at the time of the damage when starting from zero. So one can derive from Article 6(4) that the member states have a legal duty to conserve sufficient potential Natura 2000 sites outside the Natura 2000 network, i.e. sufficient habitats of bird species of Annex I of the Birds Directive or migratory bird species, and habitats from Annex I of the Habitats Directive and from species of Annex II of the Habitats Directive. Often the habitats that didn't meet the selection criteria from the Birds and Habitats Directives (usually degraded habitats) can be upgraded and designated as a Natura 2000 site, and this is in many cases better than a start from zero, merely beginning with the expropriation of (agricultural) land. Furthermore, by conserving potential Natura 2000 sites outside the Natura 2000 network, one can improve the connectivity of the Natura 2000 network, also in light of adapting Natura 2000 to climate change.

\footnotetext{
${ }^{75}$ Guidance Document, supra note 5, at 13.

${ }^{76}$ Guidance Document, supra note 5, at 16.
} 


\section{Biological Integrity vs. MAN-MADE NATURE-The ACHELOOS RIVER CASE}

The guidance document stresses the biological integrity of Natura 2000. Compensatory measures under the Habitats Directive must be established according to reference conditions that are defined after the characterisation of the biological integrity of the site likely to be lost or deteriorated, and according to the likely significant negative effects that would remain after mitigation. Biological integrity can be defined as all those factors that contribute to the maintenance of the ecosystem including structural and functional assets. In the framework of the Habitats Directive, the biological integrity of a site is linked to the conservation objectives for which the site was designated as part of the Natura 2000 network. ${ }^{77}$ Once the biological integrity likely to be damaged and the actual extent of the damage have been identified, the measures in the compensation programme must specifically address those effects, so that the elements of integrity contributing to the overall coherence of the Natura 2000 network are preserved in the long term. ${ }^{78}$ The area selected for compensation must have-or must be able to develop-the specific features attached to the ecological structure and functions, and required by the habitats and species populations. This relates to qualitative aspects like the uniqueness of the assets impaired and it requires that consideration be given to local ecological conditions. ${ }^{79}$ In recent cases $^{80}$ submitted for a Commission opinion, it seems that Germany has delivered detailed explanations, per habitat type, also quantitatively, of the proposed compensatory measures.

In 2012, the case of the Acheloos River in Greece was judged by the Court of Justice ${ }^{81}$ on a reference for a preliminary ruling (as a result of no less than 14 questions by the Greek Council of State). The controversial Acheloos diversion scheme is more than 80 years old and is a huge project, deviating the course of the Acheloos River and making it flow into the Aegean instead of the Ionian Sea. The river has its source in the Pindus mountains, it flows through Natura 2000 sites and has a delta with an enormous nature value. Despite actions by environmentalist groups,

\footnotetext{
${ }^{77}$ Guidance Document, supra note 5, at 15.

${ }^{78}$ Guidance Document, supra note 5, at 16.

${ }^{79}$ See Guidance Document, supra note 5, at 18.

${ }^{80}$ E.g. opinions in Karlsruhe Airport, Lübeck Airport, etc.

${ }^{81}$ See P. De Smedt, Heikele Toepassingsvragen bij de Kaderrichtlijn Water, in Relatie tot de Habitatrichtlijn, Naar Aanleiding van een Omstreden Griekse Rivieromleiding (annotation Case 43/10), 2 TIJDSCHRIFT VOOR MiLIEURECHT 153-169 (2013); H. Schoukens, Omlegging Griekse Rivier: de Mythe van "groene" Infrastructuur Projecten, 1 TIJDSCHRIFT VOOR OMGEVINGSRECHT EN OMGEVINGSBELEID 67-69 (2013).
} 
numerous judgments annulling government decisions by the Greek Council of State and even a ban in the 1990s by the EU Commission, parts of the project, consisting of the construction of hydro-electric dams and associated reservoirs and tunnels, have already been completed in the last couple of decades, with many landscape destroying construction works around the river and leading to a dramatic drop in the water supply by the river in the delta. The river water is being deviated to the Thessaly plains mainly to irrigate the maize and cotton fields. ${ }^{82}$

The Court of Justice acknowledged that the supply of drinking water, one of the reasons that Greece relied upon for justifying the project, can be seen as an imperative reason of overriding public interest relating to human health in the sense of Article 6(4) of the Habitats Directive, and sees irrigation as a possible imperative reason of overriding public interest but not relating to human health. The Court even stated in general that irrigation could be related to beneficial consequences of primary importance for the environment, ${ }^{83}$ which can be seriously doubted if it is, as in this case, for the cultivation of maize and cotton. Particularly interesting for this contribution, however, it is what the Court of Justice ruled in relation to compensatory measures. On the one hand, the Court stated that the extent of the diversion of water and the scale of the works involved in that diversion are factors that must be taken into account in order to identify with precision, the adverse impact of the project on the site concerned and, therefore, to determine the nature of the necessary compensatory measures in order to ensure the protection of the overall coherence of Natura $2000 .{ }^{84}$ Thus, it seems that in this case huge compensatory measures have to be taken. On the other hand, the Court ruled that the compensation obligation laid down in Article 6(4), interpreted in the light of the objective of sustainable development, ${ }^{85}$ as enshrined in Article 6 TFEU, permits, in relation to sites which are part of the Nature 2000 network, the conversion of a natural fluvial ecosystem into a largely man-made fluvial and lacustrine ecosystem provided that the conditions are met to ensure the protection of the overall coherence of Natura $2000 .^{86}$ With this last statement, i.e. that a natural ecosystem may be

\footnotetext{
${ }^{82}$ http://www.balcanicaucaso.org/eng/Regions-and-countries/Greece/Greece-fight-for-the-soul-ofthe-Achelous-River-128205 (last visited November 19, 2014).

${ }^{83}$ Case 43/10, supra note 2, Para. 125.

${ }^{84}$ Case 43/10, supra note 2, Para. 132.

${ }^{85}$ Sustainable development is only ensured when both intergenerational (environmental protection) and intragenerational (fair economic and social development) equity is ensured and equally considered through the decision-making (V. Barral, Sustainable Development in International Law: Nature and Operation of an Evolutive Legal Norm, 23 EJIL 380-381(2012)).

${ }^{86}$ Case 43/10, supra note 2, Para. 139.
} 
compensated by a man-made ecosystem, the Court did not really adhere to the requirements for biological integrity and ecological functionality in the Guidance document. The question even arises if it is not a contradictio in terminis that by conversing natural ecosystems in man-made ecosystems one can ensure a long-term protection of the coherence of Natura 2000, and certainly, in contrast to the Court's view, this is not the purpose of sustainable development ${ }^{87}$ (perhaps except for saline deserts when there is no longer a more natural alternative ${ }^{88}$ ). But avoiding and minimizing encroachments in natural ecosystems certainly is. ${ }^{89}$

\section{The Costs of the Compensatory MeAsures: Opinion OF the COMMISSION}

The Habitats Directive remains silent about the question that bears the costs of the compensatory measures, but as the Guidance document ${ }^{90}$ puts it, it appears logical that, in line with the "polluter pays" principle, the promoter of a project bears these costs. A subsidy granted by a public authority for measures taken in order to compensate for damage to a Natura 2000 site can be considered as a state aid (within the meaning of Article 87 (ex 92) EC, should it be granted to an undertaking established in a Natura 2000 site, designated before or after the establishment of the undertaking. However, in the case of an undertaking acting as a contractor for a public authority to build an infrastructure, the subsidy would not be considered as a state aid as long as it is granted in exchange of works carried out.

The compensatory measures should be submitted to the Commission before they are implemented and indeed before the realization of the plan or project concerned, but after its authorization. It is therefore advisable that compensatory measures should be submitted to the Commission as soon as they have been adopted in the planning process in order to allow the Commission, within its competence of guardian of the treaty, to assess whether the provisions of the Habitats Directive are being correctly

\footnotetext{
${ }^{87}$ Compensatory habitat creation can probably be used in some wetlands and intertidal environments, but the prospects for success in many terrestrial situations are far less certain (R. Morris et al., The Creation of Compensatory Habitat - Can it Secure Sustainable Development?, 14 J NAT CONSERV 106 (2006)).

${ }^{88}$ See D.A. Jones et al., Sabah Al-Ahmad Sea City Kuwait: Development of a Sustainable Man-made Coastal Ecosystem in a Saline Desert, 15(1) Aquatic Ecosystem Health \& MANAGEMENT 84-92 (2012).

${ }^{89}$ See also H. Schoukens, Omlegging Griekse Rivier: De Mythe van "Groene” Infrastructuur Projecten, 1 TIJDSCHRIFT VOOR OMGEVINGSRECHT EN OMGEVINGSBELEID 67-69 (2013).

${ }^{90}$ Guidance Document, supra note 5, at 20.
} 
applied $^{91}$. But, according to Article 6(4) second paragraph, whenever the plan or project concerns a site hosting priority habitats or species and is likely to affect these priority habitats or species, the realization of plans or projects likely to adversely affect these sites could be justified only if the evoked imperative reasons of overriding public interest concern human health and public safety or overriding beneficial consequences for the environment, or if, before granting approval to the plan or project, the Commission expresses an opinion on the initiative envisaged. Since the Birds Directive does not rank any species as priority, compensatory measures aiming to offset effects on specially protected areas' bird populations would never require the Commissions' opinion. The Commission, in delivering its opinion, should check the balance between the ecological values affected and the invoked imperative reasons, and evaluate the compensation measures. The opinion is not binding but in case of non-conformity with Community law, legal action may be taken ${ }^{92}$.

\section{DEROgATIONS FROM SPECIES PROTECTION AND COMPENSATORY MEASURES}

Also in the framework of derogations from the species protection regime of the Habitats Directive ${ }^{93}$, similar questions about compensatory measures as in the framework of Article 6(4) of the Habitats Directive can arise. Here too the European Commission services provided guidance ${ }^{94}$.

According to Article 12(1) member states "shall take the requisite measures to establish a system of strict protection for the animal species listed in Annex IV (a) in their natural range, prohibiting (...) (d) deterioration or destruction of breeding sites or resting places". According to Article 13(1), member states "shall take the requisite measures to establish a system of strict protection for the plant species listed in Annex IV (b), prohibiting (a) the deliberate (...) uprooting or destruction of such plants in their natural range in the wild (...)”. Article 16(1) gives the member states the possibility to derogate from the mentioned provisions for specifically mentioned reasons of public or private interest (e.g. for

\footnotetext{
${ }^{91}$ Guidance Document, supra note 5, at 21.

${ }^{92}$ Guidance Document, supra note 5, at 24.

${ }^{93}$ G. Nardell, A Disturbance in the Law? Implications of Recent Case Law on the Species Protection Provisions of the Habitats Directive, 9 JPL 1155-1173 (2011); A. Pillai \& D. Heptinstall, Twenty Years of the Habitats Directive: A Case Study on Species Reintroduction, Protection and Management, 15(1) ENV. L. REV. 27-46 (2013).

${ }^{94}$ European Commission, Guidance Document on the Strict Protection of Animal Species of Community Interest under the Habitats Directive 92/43/EEC 88 (2007). Available at http://ec.europa.eu/environment/nature/conservation/species/guidance/pdf/guidance_en.pdf.
} 
imperative reasons of public interest, including those of a social or economic nature, or to prevent serious damage to property), but only under the condition "that there is no satisfactory alternative and the derogation is not detrimental to the maintenance of the populations of the species concerned at a favourable conservation status in their natural range" 95 . Particularly the provision for direct habitat protection of Article 12(1) can be important for habitat conservation outside Natura 2000. The Court of Justice $^{96}$ has already ruled that Greece violated this provision by not halting the traffic of motorbikes on the beach damaging the nests of sea turtles. Recently the Court ${ }^{97}$ has, in the case about the wild hamster in the Alsace region, ruled that France failed to implement this provision. The hamster population dropped to $20 \%$ in seven years' time, mainly due to habitat degradation caused by urbanization and agricultural changes such as maize cultivation instead of certain cereals. France has to adjust its agricultural and urbanization policies sufficiently to protect the hamster. It is clear that this provision is not only of importance to the hamster, but also to a lot of species of Annex IV (a).

Article 16(1) requires the member states to search for the most satisfactory alternative (in light of the protected species) and to take measures to maintain a favourable conservation status for the protected species, while granting derogation from the protection measures of Articles 12(1) and 13(1). An appropriate assessment of the impact of a specific derogation will normally have to be at a lower level than the biogeographical level (e.g. site, population level) in order to be meaningful in the specific context of the derogation ${ }^{98}$. One way to maintain a favourable conservation status for the protected species can be to oblige the promoter of the damaging project to take compensatory measures, or as the Guidance document states in the case of the deterioration or destruction of breeding sites and resting places "derogations can be more easily justified if sufficient compensatory measures are taken to offset the impact at population and biogeographic levels"

All of the characteristics of compensatory measures under Article 6(4) discussed above (in-kind, simultaneousness, etc.) are also valid here, and as in the case of Article 6(4), a sound assessment of the alternatives is only

\footnotetext{
${ }^{95}$ According to article 16(2) of the Habitats Directive member states shall forward to the Commission every two years a report in accordance with the format established by the Committee on the applied derogations and the Commission shall give its opinion on these derogations.

${ }^{96}$ Case 103/00, Commission v Greece, ECR I-01147 (2002).

${ }^{97}$ Case 383/09, Commission v France, ECR I-04869 (2011).

${ }^{98}$ Guidance Document Species Protection, supra note 94, at 61.

${ }^{99}$ Guidance Document Species Protection, supra note 94, at 62-63.
} 
possible including the mitigation measures and independent of the compensatory measures; all this is stressed in the guidance document ${ }^{100}$.

But it seems that compensatory measures beforehand (e.g. through habitat banking) or former nature development measures can enhance the conservation status of the concerned species, and by doing so, making it unnecessary to compensate at a later moment when derogations are granted, and this is different from the situation under Article 6(4), requiring compensatory measures as such. If one reads the guidance document ${ }^{101}$ on this point, one sees that the Commission services are struggling with this difference. They refuse to call these kinds of compensatory measures and come up with the new term "CEF measures", or in full "measures that ensure the continued ecological functionality of a breeding site/resting place". According to the guidance document, ${ }^{102}$ these new kinds of measures include mitigation measures and preventive measures such as improvement of the management of habitats or even creating new habitats.

\section{CONCLUSION}

The obligation to take compensatory measures under Article 6(4) of the Habitats Directive, as interpreted by the Court of Justice and in the Commission's guidance and practice and in (legal) doctrine, appears to be a strong legal duty for the member states. Compensatory measures differ from mitigation, former nature development, and usual nature conservation measures. Recent case law of the Court in the Briels case supports this view. By doing so, compensatory measures have an added ecological value and do not jeopardize an appropriate assessment of alternative solutions, neither are they means to circumvent an appropriate assessment of the project's negative impacts. Compensation has to be in-kind, feasible and simultaneous with the damaging activities, in order to ensure the coherence of the Natura 2000 network, and overcompensation (or compensatory remediation) is the norm while compensatory habitat needs time to develop in order to reach the same ecological quality as the damaged habitat. Recent case-law of the Court in the Acheloos River case however lets too much room for the creation of man-made ecosystems as compensatory habitats. We hope that the concerned passage in the judgement is a passing fad and that the Court continues to contribute to a sound interpretation of European nature conservation legislation.

\footnotetext{
${ }^{100}$ Guidance Document Species Protection, supra note 94, at 63.

${ }^{101}$ Guidance Document Species Protection, supra note 94, at 47.

102 Guidance Document Species Protection, supra note 94, at 47.
} 
Within the framework of Article 16(1), the Member States have only the legal duty to maintain the concerned protected species in a favourable conservation status. Compensatory measures are one way to achieve that status (besides e.g. former nature development measures) and this is different from the situation under Article 6(4), requiring compensatory measures as such. 